\title{
Renu Chakraborty and the Women's Movement in India: A Journey for Equality and Empowerment of Women
}

\author{
Dr. Paramita Bhadra (Sur Ray) \\ Assistant Professor \\ Vivekananda College \\ West Bengal, India.
}

\begin{abstract}
Renu Chakraborty was a pioneering women in Indian women's movement. Inspired by communist ideal she firmly believed that women's emancipation could be achieved if a society free from feudal oppression and exploitation could be achieved. In India she found that millions of Indian women were in chains. They did not have any rights whatsoever. Renu played an active role in arising consciousness about their degraded status. She also played an active role in eradicating social evils that were prevalent in Indian society.
\end{abstract}

Keywords: women, empowerment, society, oppression.

Renu Chakraborty largely influenced by Communist ideals became one of the pioneering Bengali women playing a constructive role in the women's movement and their social uplift. Born into a well-to-do and educated family she was never afraid to take up challenges. She firmly believed that women's emancipation could be achieved if a society free from feudal oppression and exploitation could be established. In India both before and after independence she played an important role in almost all the key issues concerning women.

\subsection{Early Years: Key Influences}

Renu was born in an affluent Brahmo family. Social activism was in her blood as both her paternal grandmother Aghorkamini Ray and her mother Brahmmoyi Devi were involved in various social welfare activities for women all through their lives. These two women had a profound influence upon Renu which was later reflected in her body of work. She during her growing years was very much influenced by Gandhian movements as she felt that Gandhi's call to defy British laws had no gender discrimination. She also admired the women who were involved in revolutionary activities as they fought shoulder to shoulder with men and through their sacrifice and even martyrdom in some cases had contributed towards the cause of the country's liberation. It was during her stay in Cambridge as a student that she witnessed the Fascist invasion of Checkoslavakia. As she was reared in the democratic values of the national movement in India it was only natural for her to hate Fascist ideals of racial superiority and anti-Semitism. It was in 1938 in England that she came under the influence of the famous Communist leader Rajani Palme Dutt and joined the Communist Party.It was also in England as a student that she first came to realize that the fight for India's freedom should bring social justice for the downtrodden. ${ }^{1}$ She was also influenced by personalities like John Strachey and realized that status quo of the society needed to be changed so that the masses could enjoy the fruits of their labour. In 1939 she returned to India and joined the Communist Party in India.

\subsection{Creating Awareness among women}

Back home the twin objectives of fighting against British imperialism and standing for the social justice of the toiling masses became intertwined in her consciousness. She strongly felt that women could play a vital role in this task as women constituted more than half the population. So if they joined forces anything could be achieved. But Indian women, she noticed, was '. . .weighed down by the millstone of feudal backwardness. Ignorance, illiteracy, superstitions held them in an octopus grip.' ${ }^{2}$ They were married early and constant child-bearing without proper medical care and nutrition increased the rate of maternal and child mortality. They were economically dependent on men and age-old social edicts kept them secluded in society. Therefore, it was an uphill task to bring women into the movement against the colonial rule as well as in the movement to establish a just social order.

\footnotetext{
${ }^{1}$ Renu Chakraborty, Communists in Indian Women's Movement (1940-50), New Delhi, 1980, p.5.

${ }^{2}$ Ibid, p.6.
} 
Therefore in India, she reflected, the struggle for women's emancipation had a political and economic importance, even if the social demands of women had to be fulfilled. ${ }^{3}$

After her return she plunged herself into the movement for the release of prisoners which was at its peak in Bengal. At this time students were very active in this movement. It was at the end of 1939 that she attended the national conference of the All India Students' Federation (AISF). As women students actively took part in meetings and demonstrations throughout this movement the need to organize girl students became a priority. But there were many hurdles in this path. The leadership of the students' organisations were predominantly male and there were very few co-educational colleges. That is why the AISF decided to set up a Girl Students' Committee. In 1940 the first ever all India meet of women students took place in Lucknow. Sarojini Naidu was the chief guest of the conference while Renu was the president. As president she communicated to the audience of the menace of fascism which was actually the extreme face of imperialism. Renu argued that in those days the girl students were the only educated cadres among the women and were the main organisers of the women's movement. ${ }^{5}$

During the early part of 1940 when World War II escalated to Asia when the Japaneese forces started advancing towards the borders of India. In 1942 the Quit India movement was launched and almost immediately all the important leaders, including Gandhi were arrested by the British Government. In October, 1942 the Communist party in Bengal formed a Provincial Women's Front and Renu was selected as one of its members. In December, 1942 Japan bombed Calcutta. This created a sort of panic among the people. Communist women now started their door to door campaign trying to convince them that in order to defend their country as well as the honour of women they had to build national unity and also secure the release of the national leaders. But the task ahead for the women volunteers was by no means an easy one, as sharp social barriers stood against women volunteers moving freely among women who were steeped in conservatism. ${ }^{6}$ Renu wrote that people '. . thought us to be a peculiar type of women going all over the area from house to house, shamelessly talking to everybody. ${ }^{, 7}$ Renu recalled that many were sympathetic to them as they raised issues which affected their daily life but a section of menfolk used to make sarcastic remarks and asked their wives to stay away from them. Despite such adverse circumstances women workers carried on their activities and gradually spread their roots.

But initially the problem was how to draw together women for a meeting and more importantly to hold their attention for long. The workers then were few in numbers. When it was decided that a meeting was to be convened in a particular area the workers used to go door to door more than once, often convincing them to come to the meeting at the last minute. The women used to come with their kids and crying babies. Often, women lost interest in course of the meeting and started talking amongst themselves. To counter this, the workers like Renu had to evolve the method of simple dramas to carry their message through the visual world. ${ }^{8}$ She wrote:

We, the organisers, worked in a multi-purpose manner. We arranged the meeting place, did the propaganda for the meeting among the women, went around collecting them, spoke to them of the issues which were of importance, and last but not the least, acted for them, sang and danced for them, in order to convey what we were trying to say through a cultural form which caught their imagination. ${ }^{9}$

Their hard work gradually paid off. Women began to start samitis in their areas and also moving about into their own neighbourhood.

Around April, 1942, women workers like Kamala Chatterjee, Manikuntala Sen, Ela Reid and Renu met and felt the necessity of coordinating the activities of all the women's organisations that were springing up in different parts of Bengal. It was then decided, that an organising committee of the Mahila Atmaraksha Samiti (Women's Self-Defence League) would be established. Renu wrote: ' . . s so the first seeds were sown, out of which was to sprout a big mass organisation of women throughout Bengal's districts. ${ }^{\text {, }}$

Around this time the terrible food crisis started erupting in Bengal. When the Japanese army occupied Rangoon in March, 1942 rumours started floating that the cheap Burma rice would no longer be available. As precautionary measure, the British destroyed all country-boats in the coastal areas.

\footnotetext{
${ }^{3}$ Renu Chakraborty, Communists in Indian Women's Movement, p.7.

${ }^{4}$ Ibid, p. 10.

${ }^{5}$ Ibid, p.11.

${ }^{6}$ Ibid, p. 18

${ }^{7}$ Ibid, p. 18.

${ }^{8}$ Ibid, p.19.

${ }^{9}$ Ibid, pp.19-20.

${ }^{10}$ Ibid,p. 21 .
} 
Agricultural activities were banned as part of British defence preparations. All these led to an acute food shortage. When the Allied troops started arriving airfields began to be constructed in the interior areas. The prices of rice began to rise abnormally, as the hoarders and black marketers started hoarding rice and it nearly disappeared from circulation. The villagers started trekking towards the city of Calcutta in search of food. Calcutta saw the horrible sight of humans and dogs searching for food from the same dustbin or a mother snatching morsel of food from her own child. 'Women were just skin and bone and their children gasping for their last breath., ${ }^{, 11}$

But government relief was rather inadequate. To put pressure on the government the Calcutta MARS and the Muslim Women's Self Defence League organized the first ever hunger march to the Assembly on $17^{\text {th }}$ March, 1943.This was organised at a time when marching to the Assembly was little known. Renu wrote:

The demonstrators in their tattered rags and with babies in arms, famished and emaciated, marched before the eyes of Calcutta's public, telling them what words failed to do, of their pitiful plight. ${ }^{12}$

Their demand was for more shops, proper supply especially in slums and bringing down the price of rice to the control rate of Rs.13.25 per maund. The demonstrating women pointing to the coins tied to the end of their sari told the members of the Assembly that they had come not to beg but to demand rice at pre-famine rate. At first the Bengal premier, Fazlul Haque pleaded helplessness but as the women were adamant he ordered hundred bags of rice to be distributed amongst the demonstrators on the spot. About the uniqueness of the demonstration she wrote: 'For the first time a women's organisation had taken to the path of agitation and that too in the form of a demonstration. ${ }^{, 13}$ Following this, women organized hunger marches in different districts. About their importance Renu wrote:

Through these first direct actions, which for women of those days in the villages and among the urban poor, was a big step, the consciousness began to dawn that they could survive only through movements; and for movements to begin there must be collective organisation. ${ }^{14}$

Rehabilitating the destitute women was another uphill task that the women workers took upon. When in 1944 MARS and other organisations joined hands to form the Nari Seva Sangha- a representative central co-ordinating body to focus attention on the entire problem of relief and rehabilitation of the women afflicted during the famine and afterwards Renu was one of the guiding force behind this initiative. The main work of NSS was to open homes and handicraft centres in different districts.

As soon as the effects of the famine had somewhat subsided, the sharecroppers in Bengal rose in protest against an unjust system. This was known as the Tebhaga movement. The sharecroppers were hard hit by the famine. Many small peasants were forced to sell their land during the famine and thus there was an increase in the number of aharecroppers. A section of the jotdars (a big and rich farmer) accumulated huge money at their expense. Meanehile, from 1938 the Kishan Sabhas had started propagating their aim to end the Zamindari system and to argue that tebhaga (two-thirds of the crops) was to be given to the sharecroppers. In November, 1946 when the paddy was ready for harvesting the movement started in a number of districts in Bengal. The women became the principle force behind the movement. When the leaders became underground, and the repression became extreme, it was the women who arranged for their shelter, their succor and their security. ${ }^{15}$ It was during this movement that women like Renu came to realize that apart from economic exploitation, rural women were subjected to physical abuse by their husbands. Not only that, their husbands used to drink too much, forcefully taking away the money, which their women had earnedfrom selling vegetables grown in the backyard or goat or cow's milk, eggs or fish. During the movement women started raising these issues before the party leaders. It was due to their pressure that a resolution was passed by which wife-beating was forbidden. The party also had to pronounce the verdict that the money women earned through petty trade was stree-dhan (money owned by women). ${ }^{16}$ So in course of their economic struggle rural women also came to learn how to fight for their rights and lead a life of dignity, and more importantly, to fight for equality with men. ${ }^{17}$ Thus when rural women were trying to come out of their shackles Renu and Manikuntala Sen, who were close comrades, tried to convince their leaders that women's problems neededto be addressed along with issues of economic exploitation.

\footnotetext{
${ }^{11}$ Renu Chakraborty,Communists in Indian Women Movement, p.27.

${ }^{12}$ Ibid, p.29.

${ }^{13}$ Renu Chakraborty, “New Perspectives For Women's Movement-After 25 Years of Drift,” Link, vol.15, Aug-Oct, 1972.

${ }^{14}$ Renu Chakraborty, Communists in Indian Women Movement, pp.33-34.

${ }^{15}$ Communists in Indian Woman's Movement, p.94.

${ }^{16}$ Ibid , p.8

${ }^{17}$ Ibid, p.89. 
Meeting time needed to be decided according to the convenience of the women. Renu also suggested if more and more women were to play a leading role something needed to be done to free them from household work. ${ }^{18}$ Steps should also needed to be taken to protect women from abusive husbands. But the party wanted to put the struggle above personal concerns. ${ }^{19}$ Nevertheless, As Renu argued:

Kisan women rose from their age-old slumber to breathe the air of a new awakening. That awakening came to them through the great and glorious Tebhaga struggle of Bengal in 1946-47. ${ }^{20}$

\subsection{Fighting the Age-old Customs}

Renu was eager to fight against the laws and customs that had put women in chains which she termed as feudal. The saying in the scriptures: 'A girl is subjected to the father as a child, her husband in youth, to her son in old age,' according to Renu explained the humiliating status of women that had been handed down from feudal traditions. ${ }^{21}$ She wrote that in India strong vestiges of feudalism and its reactionary ideas had great hold on the minds of both men and women and nothing substantial could be achieved without a tremendous all-out campaign against feudalism. ${ }^{22}$ Issues like ignorance, superstition, lack of education, women's economic dependence on men, her inferior position in marriage, inheritance, the curse of dowry-all needed to be addressed. At first women activists were in favour of one universal code for the whole of India. But they had to drop this idea initially, as there was strong opposition to it. Instead, they decided to deal with the issues separately in the hope that uniformity would come step by step. The issues of Hindu Code on marriage, inheritance etc. was first taken up. In 1941 the government had appointed the Rao Committee to make necessary changes in Hindu laws with regard to marriage, inheritance etc. In order to explain to ordinary women the real need and aim for changing the laws of inheritance and marriagecommunist women organised big and small meetings both in Calcutta and other areas. The MARS also started a signature campaign throughout Bengal. But opposition towards the bill was so strong that before independence the Hindu laws could not be changed.

After independence women activists thought now there would not be any hindrances to the passing of the Hindu Code Bill. But nothing happened during the tenure of the Constituent Assembly due to the opposition of the conservative section of the Assembly. After the first general election in 1952 the Hindu Code Bill was brought in the parliament. The Bill had two parts: (1) Special Marriage Bill and (2) Hindu Marriage and Divorce Bill. These bills created hue and cry among the conservative section as both these bills proposed to grant women the right of divorce in some cases. The derogative mentality of the conservative section was manifested when they argued that women would misuse the right of divorce. Addressing such people she told in the Lok Sabha on $20^{\text {th }}$ May, 1954:

...when one enters marriage one should enter it with a full sense of responsibility both towards oneself and his partner and towards the children that one is hoping to bring into the world as well as society. ${ }^{23}$

She argued that when such a situation was not possible then it would be much better for all concerned to part with honour and understanding. ${ }^{24}$ To assuage the fear of the conservatives that the right to divorce would be misused she put forward the following arguments: (1) that women were conservative and home-builders and their natural tendency was to cling to their homes and children, (2) most of the women were economically dependent on their men. ${ }^{25}$ Therefore, unless women became financially self-sufficient, unless they attained the right to inherit property, most of the women, in reality would not be in a position to take advantage of these social laws. ${ }^{26}$ She also referred to Travancore, Cochin, Mysore and Madras where Hindu women were enjoying the right to divorce without ruining the society. ${ }^{27}$ Regarding the welfare of the children, she argued that it was harmful to expose children to daily harassment and abuse of their mothers in the hands of their fathers. ${ }^{28}$ After fighting a long battle both inside and outside the parliament the women activists emerged victorious when the Hindu Code Bill was passed in 1955. Renu, however, believed that there should be a Uniform CivilCode. About its importance she said:

\footnotetext{
${ }^{18}$ Renu Chakraborty's interview with Geraldine Forbes, cited in Women in Modern India, (New Delhi: Cambridge University Press, 1996), p.215.

${ }^{19}$ Women in Modern India, p. 215.

${ }^{20}$ 'New Perspectives For Women's Movement-After 25 years of Drift," Link, p.95.

${ }^{21}$ Communists in Indian Women's Movement, p. 185.

${ }^{22}$ Ibid, p. 185 .

${ }^{23}$ Lok Sabha Debates, vol.5, nos.61-74, 1954, p.7944.

${ }^{24}$ Ibid, p.7945.

${ }^{25}$ Renu Chakraborty, "Parliamente Bibaha Sankranta Bill Duti” (The Two Marriage Related Bills in the Parliament), GhareBaire, Sravan, 1361(B.S), p.255, S.B. File no.S-565/49(iii). West Bengal Police Archive.

${ }^{26}$ Ibid, p, 255

${ }^{27}$ Ibid, p. 155 .

28،Parliamente Bibaha Sankranta Bill Duti" (The Two Marriage Related Bills in the Parliamentp.155.
} 
We need a codified law. And a more progressive outlook regarding marriage as a contract, based on love, respect for each other, and the building up of a happy home for our children. ${ }^{29}$

But she found that opposition to it was so strong that the government was reluctant to take up the issue. Therefore she believed that a big educative campaign needed to be undertaken by the government, the political parties, women's and other organisations to bring about the desired change in the personal law especially of the minority community because only legal stepe could not fight religious fanaticism. ${ }^{30}$

In order to enable to women to exercise the right to divorce in case of abusive marriage it was extremely important to give women some sort of financial power. Women till then were financially completely dependent on their men. Therefore it was important that women got the right to inherit their father's property. In this case, too, the conservative section vigorously opposed this move to give women a share in their father's property. Renu, however, was surprised to see that even a section of women opposed the move. For example, Uma Nehru who was a member of the AIWC, felt that women should not have any rights over land. ${ }^{31}$ But Renu strongly arguing in favour of the move argued that menfolk needed to realize that women would not just ruin the family and that things would not come to a dead end just because women were inheriting. ${ }^{32}$ However, she believed that inheritance was not the only precondition for women's emancipation. For that women would have to cross other barriers that society had imposed upon them.

\subsection{Fighting for the rights of working class women}

An issue which was very dear to Renu was the issue of equal rights of women especially the working class women. They were even deprived of their basic right of equal wages for equal work. Though the conventions of the ILO were formally accepted, the administration still flouted the principle of equal pay for equal work on the question of minimum wages. ${ }^{33}$ She referred to a number of references to prove her point. She pointed out that a male agricultural labourer's wage in itself was very low, but the wages of women were only $2 / 3$ that of men. ${ }^{34}$ Similarly in bidimaking and construction work, in tea plantations where women were the finest pickers, they were paid unequal wages. ${ }^{35}$ In cashew nut industry $95 \%$ of the labourers employed were women and they had to work in a hazardous environment for almost eight hours daily which fetched them an average daily wage of eight annas only. ${ }^{36}$ Women had to work amidst the harmful fume that used to emanate when cashew was fried and the juice that used to come out when the skin of the nuts were peeled off caused damage to the skin. Not only that fraudulent means were adopted to weigh the nuts in such a way that the workers got less than that was due to them as their daily wage. Renu herself visited a number of factories and saw that many under-age girls and aged women were employed in this industry, nor there were crèches for the children in the factories and in places where such facilities did exist, the amenities were very poor. ${ }^{37}$ Renu also observed that factory owners devised new ways to cheat the workers. For example, the factory owners often closed down their factories for few months and in accordance with the labour law they were to pay compensation to the workers for that period. In order to avoid giving the workers what was their due, the owners had tried to enlist the cashew-nut industry as a seasonal industry, because in that case the owners were not to liable to pay any compensation. ${ }^{38}$ In face of such deprivation Renu found the workers had started organizing themselves against retrenchment and payment of less wages and for placing demands for such facilities as child-health care and crèche facilities. ${ }^{39}$ In the 1950 s the sectors like coal, jute and textile showed a downward trend with regard to the number of women employees. The tea plantations in Darjeeling and Assam also showed similar trend. Indian society was still insensitive towards the question of women's employment and a number of irrational arguments were put forward to explain this decline. It was argued that women were primarily subsidiary earners. But Renu argued that most women due to lack of education and any skills had to take up the most unremunerated jobs to support their husband's income as it was hardly enough to sustain his family. ${ }^{40}$

\footnotetext{
${ }^{29}$ Lok Sabha Debates, vol. 3, nos.1-17, 1953, p.2324.

${ }^{30}$ Renu Chakraborty, "Communist Party and Status of Women," New Age, p.11.

${ }^{31}$ Lok Sabha Debates, vol.4, nos.46-60, 1956, p.7162.

${ }^{32}$ Ibid, 1956,p. 7686.

${ }^{33}$ Renu Chakraborty, “Communist Party and Status of Women,” New Age, p.11.

${ }^{34}$ Ibid, p.11.

${ }^{35}$ Ibid, p11.

${ }^{36}$ Renu Chakraborty, "Bharatiya Kaju Badam Silper Nari Sramik," (Women Labourers of the Cashew-Nut industry in India), Swadhinata, 31.10.1954, p.5.

${ }^{37}$ Ibid,p.5.

${ }^{38}$ Ibid, p.5.

${ }^{39}$ Ibid, p.5.

${ }^{40}$ Lok Sabha Debates, vol.17, nos.61-64, 1958, p.14365. 
It was also argued that women due to their lack of physical ability were incapable of hard work. But Renu witnessed just the opposite in iron-ore mines where men used to do the blasting and after that the entire job of carrying the heavy load of ore was that of the women. ${ }^{41}$ Another irrational argument was women were unable to handle advanced techniques of machines. But Renu argued in some foreign countries women were able to handle advanced techniqus of machines after they were provided training. ${ }^{42} \mathrm{But}$ in India the employers made no such arrangements and promptly concluded that women were incapable of skilled jobs.

When some welfare measures like maternity benefit laws, laws relating to working hours for women, laws instructing employers to provide for crèches and milk for children, allowing women with babies feeding time for their children were implemented, employers instead of implementing these started sacking women as women were always considered cheap source of labour especially in mines and plantations. As these areas were still out of the bound of trade union movements women were still unaware of their basic rights. Therefore she urged the government to think seriously about these uneducated and unskilled women who were finding it difficult to get employment. ${ }^{43}$ Moving the Equal Remuneration Bill in the parliament in 1959 Renu pointed out that minimum wages must be the same for both men and women and where the nature of the job was same, certainly equal wages should be paid. ${ }^{44}$ Renu was happy to note that women had gradually become conscious of their rights and had become an integral part of the trade union movement. But here too gender bias existed as very few women were in the leading positions and majority of the workers were illiterate.

\subsection{Fight against Dowry and immoral trafficking}

Dowry was another instance of the backward mentality of the Indian society. It was a system by which in times of marriage a bride's family had to give a lump sum to the groom's family either in cash or kind or both. She found that the evil was so deep-rooted that even the educated women could not escape from its clutch. It was expected that with time and spread of education the evil would be eradicated but that did not happen. In 1958 after different women's organisations put pressure on the government to introduce an anti-dowry bill, the bill was moved in the parliament and then it was sent to a select committee, headed by Renu. Pointing to the gender bias in the society Renu pointed out that parents used to save money for their son's education and for the dowry of the daughter at the time of marriage. ${ }^{45}$ The bill was ultimately passed although there were some loopholes in the bill and for the first time in India acceping and giving dowry was declared a punishable offence. However, Renu reminded the society that all social laws unless they were backed by an awakened social conscience and a strong public opinion would remain infructuous to a very large extent. $^{46}$

Women especially from the poorer strata of the society were an easy prey to yet another social evil, i.e. immoral trafficking. Renu argued that as poverty was the main reason for women becoming its victims it was extremely necessary that the government should make elaborate arrangements to provide women a larger scope of employment. When the bill for suppression of immoral trafficking came up for discussion in the parliament, Renu agreed with the basic points like tackling poverty, opening up of employment and homes for women and educating people in high moral standards. ${ }^{47}$ But more important was to tighten the law. As the police would play a vital role in the machinery to control trafficking, they should be given proper training to work with compassion. Secondly, she felt that association of women at every stage especially in the task of rescuing was very essential. Also the responsibility of the homes for rescued women shold be entrusted upon women as male superintendents had the tendency to abuse their positions. The homes should also make arrangements for the economic rehabilitation of these women. The bill was passed in the parliament in 1956. But the act could not stop the evil. Renu believed that individual prostitution remained unpunishable under the law and as a result poor helpless girls continued to be exploited.

\section{Conclusion}

As a staunch champion of women's rights Renu believed that the Communist women had brought a new turn in Indian women's movement. She wrote:

\footnotetext{
${ }^{41}$ Lok Sabha Debates, vol. 17, nos. 61-64, 1958, p.14368.

${ }^{42}$ Ibid, p. 14369.

${ }^{43} \mathrm{Ibid}$, vol.18, nos.1-10, 1958, p.1217.

${ }^{44}$ Ibid, vol.32, nos.1-10, 1959, pp.2598-2599.

${ }^{45}$ Lok Sabha Debates, vol.36, nos.11-20, 1959, p.3711.

${ }^{46}$ Ibid, p.3710.

${ }^{47}$ Lok Sabha Debates, vol.9, nos.1-15, 1956, p.1544.
} 
Most of the organisations of women comprised of the middle and upper-middle class and their membership was limited in numbers. For the first time the peasants, workers, the downtrodden in the bustees[slums] in urban areas, the agricultural labouring women, lower middle-class women, middle-class intellectuals and students- all converged into a massive stream. The women's organisations became a big mass movement involving town and countryside. ${ }^{48}$

Renu admitted that after years of struggle women had achieved some milestones in the form of new laws regarding marriage, divorce, inheritance, but these achievements would be meaningless if millions of rural women remained in darkness and distress. Therefore a vigorous campaign had to be undertaken with the support of government and other political parties to eradicate social evils

With regard to politics she felt that party politics might be shunned, but politics that touched women must be taken up with all firmness and with as much unity as possible. ${ }^{49}$ She believed that it was the responsibility of the leaders of the women's movement to build up unity of action and understanding to organise the ordinary Indian women. Only then could India win over the forces of exploitation and set the women towards the path of real emancipation.

\section{$\underline{\text { References }}$}

Renu Chakraborty, (1980), Communists in Indian Women's Movement(1940-50), New Delhi: People's Publishing House.

Renu Chakraborty, (1972), "New Perspectives for Women's Movement after Twenty-Five Years of Drift," Link, vol.15, August-October, 1972.

Renu Chakraborty, "Communist Party and Status of Women," New Age, vol.27, September, 1974.

Geraldine Forbes, (1996), Women in modern India, Cambridge University Press.

Bengali Journals and Newspapers

Ghare-Baire

Swadhinata

Government Proceedings

Lok Sabha Proceedings.

\footnotetext{
${ }^{48}$ Communists in Indian Women's Movement, p.277.

49 "New Perspectives for Women's Movement-After 25 Years of Drift," Link,p.181. 